\title{
The Canadian
}

Journal ofLinguistics

La Revue canadienne

de Linguistique

FALL/AUTOMNE $1971-17: 1$ 


\section{Canadian Linguistic Association}

Association canadienne de

\section{Linguistique}

OFFICERS/BUREAU

President/Président A. RIgault, McGill

Past President/ Président sortant w. s. Avis, Royal Military College Vice-President/Vice-Président R.G. GREGg, U.B.C.

Secretary-Treasurer/Secrétaire-Trésorier GU Y PLASTRE, Laval

Members of the Executive/Membres du Conseil

W. LEHN, Minnesota J. HEwson, Memorial

Editor/Rédacteur E.N. BURSTYNSKY, Toronto

Associate Editor/Rédacteur adjoint p. cardinal, Ottawa

Assistant Editor/Rédacteur assistant J. K. Chambers, Toronto

The canadian journal or linguistics is the official publication of the Association. Annual dues of six dollars, which include subscription to the Journal, are payable to the Treasurer. Available back issues may also be ordered from the Treasurer, G. Plastre. Université Laval, Québec 10e.

Manuscripts in English or French may be sent to the Editor, Professor E. N. Burstynsky, Centre for Linguistic Studies, University of Toronto. A Style Sheet should be secured from the Editor before the final manuscript is typed. Books for review should also be sent to the Editor.

La revue canadienne de linguistique est l'organe officiel de l'Association canadienne de Linguistique. Le montant de la cotisation, abonnement compris, est de six dollars et doit être versé au Trésorier. Les manuscrits et toute correspondance relative à la rédaction de la Revue doivent être envoyés au Rédacteur. Les collaborateurs sont priés de demander le protocole de la Revue avant de rédiger la version définitive de leur manuscrit. Les livres pour recensions et les comptes rendus sont à envoyer au Rédacteur.

(C) Canadian Linguistic Association 1972. All rights reserved. Published by the University of Toronto Press.

The canadian journal of linguistics continues the journal of the CANADIAN LINGUISTIC ASSOCIATION.

La REVUB CANADIENNE DE LINGUISTIQUe fait suite à la REVUE DE L'ASSOCIATION CANADIENNE DE LINGUISTIQUE. 


\section{THE CANADIAN JOURNAL OF LINGUISTICS}

Fall/Automne 1971-17:1

\section{LA REVUE CANADIENNE DE LINGUISTIQUE}

\section{Contents / Sommaire}

B. E. NEWTON, Sibilant loss in Northern Greek 1

J. A. CREORE, Synchronic grammars, reconstruction, and the selection problem 16

Reviews/Comptes rendus

ROY ANDREW MILler: SAINT-JACQUes, Structural Analysis of Modern Fapanese 27

a Udrey r. Duckert: Seary, Place Names of the Avalon Peninsula of the Island of Newfoundland 63

exkeHard kottre: greenbaum, Studies in English Adverbial Usage 65

N. E. COllinge: wyatt, Indo-European /a/ 70

Report of the Annual Meeting 1971/Rapport du Congrès annuel 197174

Index, CJL/RCL 14:1(1968) - 16:2(1971) 